\title{
Environmental Geochemistry of Mine Tailings Soils in the Artisanal Gold Mining District of Bétaré -Oya, Cameroon
}

\author{
Veronica Ebot Manga ${ }^{1}$, Gladys Nchang Neba ${ }^{1} \&$ Emmanuel Cheo Suh ${ }^{2}$ \\ ${ }^{1}$ Department of Environmental Science, University of Buea, Buea, Cameroon \\ ${ }^{2}$ Department of Geology, University of Buea, Buea, Cameroon \\ Correspondence: Veronica Ebot Manga, Department of Environmental Science, University of Buea, Buea, \\ Cameroon. E-mail: ebotmangav@gmail.com
}

Received: November 27, 2016

doi:10.5539/ep.v6n1p52

\author{
Accepted: December 15, 2016 \\ Online Published: March 31, 2017 \\ URL: https://doi.org/10.5539/ep.v6n1p52
}

\begin{abstract}
Changes in trace element concentrations in mine tailings (dry and wet) were investigated in the gold mining area of Bétaré-Oya, Eastern Cameroon. Forty-one surface sediment samples were analyzed using ICP-MS for heavy metals and pollution was assessed using Enrichment Ratio and Geo Accumulation Index (Igeo); using a sample from a remote area as control.Trace elements in mine tailings show significant increase compared to the background (control) values, with the exception of $\mathrm{Sr}$ and $\mathrm{Nb}$. It is suggested that allochtonous deposition may account for Sr distribution. A strong correlation is observed between the lithophile elements; $\mathrm{Y}, \mathrm{Nb}, \mathrm{Ce}, \mathrm{La}$, and $\mathrm{Pb}$. Their association with each other is also strong, i.e. $\mathrm{Nb} / \mathrm{Ce}(.73)$ and $\mathrm{La} / \mathrm{Ce}(.63)$. The close association of these elements in the samples may be an indication of the effect of resistant heavy minerals from felsic rocks (mainly granites and gneisses). $\mathrm{Cu}, \mathrm{Zn}, \mathrm{Sr}$ and $\mathrm{Ba}$ distribution is associated with mineralisation of sulphide-bearing minerals and clay formation from weathering of mica schist. $\mathrm{Cu}, \mathrm{Zn}, \mathrm{As}, \mathrm{W}, \mathrm{Mo}$ and $\mathrm{Ag}$ have been identified as potential pollutants. Compared to the Dutch soil quality guidelines, these elements are above the target values and below the intervention levels. Arsenic is considered to be the most threatening element, with regards to its potency. The distribution of As in this area appears to be controlled by mining activities.
\end{abstract}

Keywords: gold mining, trace elements, tailings, Cameroon

\section{Introduction}

\subsection{Background}

Environmental impacts due to mining are commonly associated with large-scale mechanised activities. However, several studies are reporting that artisanal, informal mining also gives rise to environmental problems (e.g. Tarras-Wahlberg et al., 2000; Hilson, 2002; Babut et. al., 2003; Waziri, 2014) and that the consequences could be more serious due to higher levels of exposure, in addition to the fact because these non-formal operations are hardly regulated by government agencies, their impact on the environment may go completely unnoticed.

During mining, a fine grind of the ore is often necessary to release metals and minerals, so the mining industry produces enormous quantities of fine rock particles, in sizes ranging from sand-size down to as low as a few microns (USEPA, 1994). These fine-grained wastes are known as "tailings". By far, the larger proportion of ore mined in most industry sectors ultimately becomes tailings that must be disposed of. In the gold industry, only a few hundredths of an ounce of gold may be produced for every ton of dry tailings generated (USEPA, 1994). These substances can be easily dispersed into the surrounding areas and can be carried off by processes of weathering into waterbodies. Tailings constitute a major source of pollution due to its potentially high chemical reactivity resulting from its large surface area. The potential for elements present in soils and sediments to be mobilised/immobilised and redistributed depends on several soil factors such as organic matter, type and amount of clay, $\mathrm{pH}$, redox conditions and cation exchange capacity (CEC). Under the right geochemical conditions such as the $\mathrm{pH}$ and the prevailing redox conditions; and pathways, these elements can easily be mobilized and transmitted through for example, water and the food chain to humans. Previous researchers have highlighted the potentially negative environmental impacts of these processes on biodiversity, ecosystem function and ecosystem services (Malaviya, Munsi, Oinam \& Joshi, 2010; Simmons et al. 2008). Amonoo-Neizer, Nyamah, \& Bakiamoh (1995) reported the significant distribution of As and Hg in the top soils, plantain, water fern, elephant grass, 
cassava and mud fish at Obuasi, (Ghana) and its environs. The aim of this work is therefore to assess trace element distribution and contamination in mine tailing from artisanal gold mining in Betare Oya, Cameroon.

\subsection{Location, Climatic Setting and Drainage}

Bétaré-Oya (Figure 1) is located on the south eastern edge of the Adamawa plateau, close to the Central African Republic (CAR) at $5^{\circ} 35^{\prime} 59^{\prime \prime} \mathrm{N}$, and $14^{\circ} 04^{\prime} 59^{\prime \prime} \mathrm{E}$. It lies in the transition zone between the equatorial forest to the south and the savannah to the north. It is found at an elevation of $779 \mathrm{~m}$ asl with a regional topography comprising largely of monotonous, ridges, deep river valleys and gently undulating plains. This area is under the influence of a tropical, humid type A wet Equatorial climate with two seasons; the wet rainy season (March to October) with abundant rainfall and a short dry season (October to mid-March) with abundant sunshine. Humidity and cloud cover are relatively high and precipitation ranges from 1500 to $2000 \mathrm{~mm}$ per year except in the extreme east and north regions where it is slightly less. Average annual temperature range from $22.8^{\circ} \mathrm{C}$ to $24.7^{\circ} \mathrm{C}$.

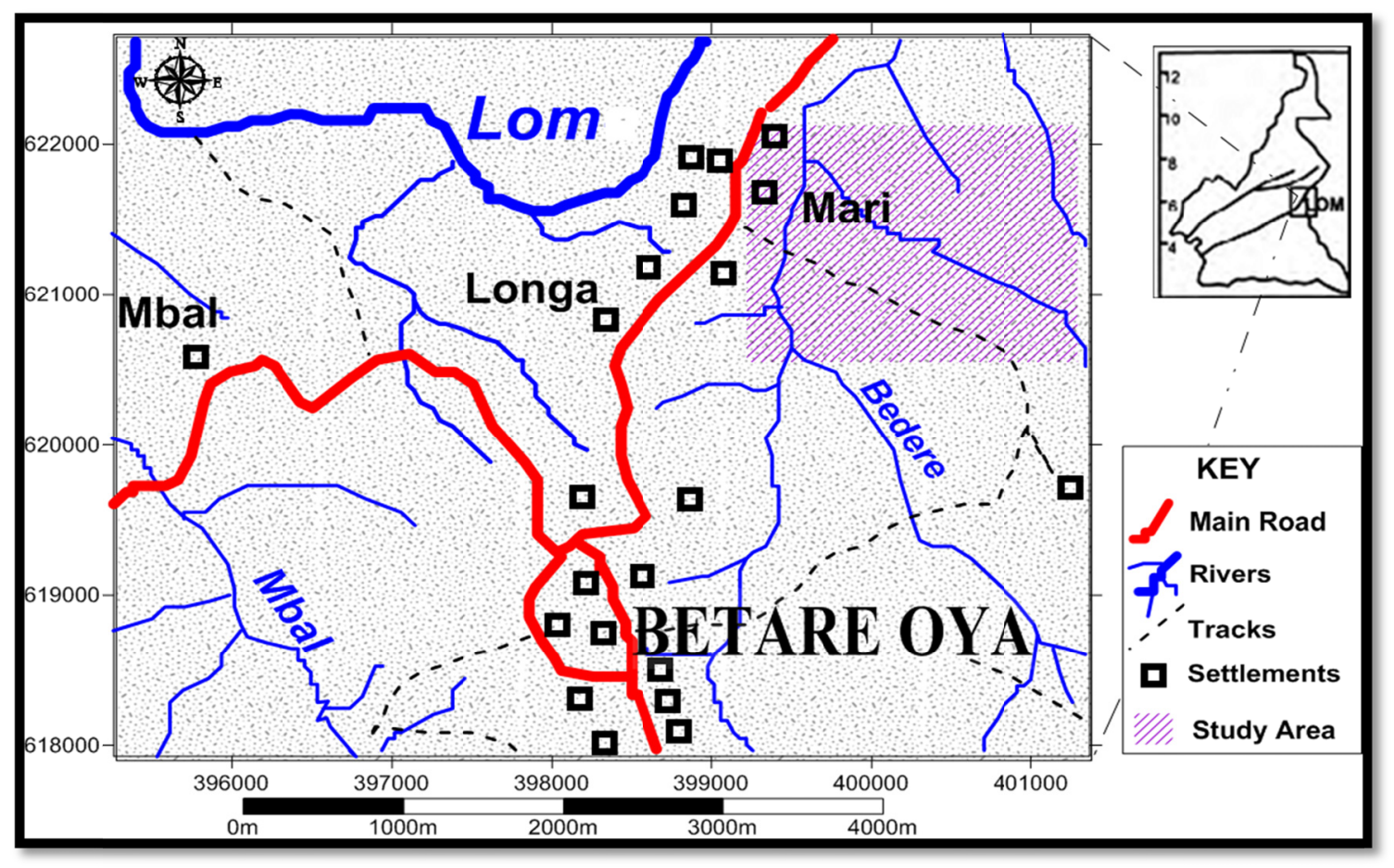

Figure 1. Map of the study area

The Bétaré-Oya gold district has several river systems that traverse the plains: the Nyong, Kadei, Boumbe and Lom rivers. These rivers flow all year round. Other secondary streams together with their tributaries also constitute a significant part of the drainage system e.g. the Mari River, Nguengue River, Mbigala, Lisso, Mbaya and Fofo, which drain into the Lom. The prevalence of metasedimentary rocks in the study area offers relatively uniform resistance to erosion, which favours dendritic configuration of the individual stream courses in the area. The vegetation is dominantly of primary nature comprising of low land tropical rain forest, which grows progressively thicker towards the south. The land area is sparsely cultivated and most of the natural vegetation is still intact.

\subsection{Geologic Setting and Gold Mineralziation}

The regional geology is dominated by the Neoproterozoic volcano-sedimentary rocks of the Lom group, metamorphosed under low- to medium-grade conditions (Suh, Lehmann, \& Mafany, 2006) and cross-cut by the Pan-African granitoids. The Lom Series is comprised of biotite schists, sericite and chlorite schists, quartzites and shales (Freyssinet, Lecomte, \& Edimo, 1989). These rocks are characterized by a NE-SW steeply dipping foliation resulting from a regional right-lateral transpressive deformation. The granites are rich in quartz $\left(\mathrm{SiO}_{2}\right)$, feldspars $\left[(\mathrm{K}, \mathrm{Ca}, \mathrm{Na})(\mathrm{Al}, \mathrm{Si})_{3} \mathrm{O}_{8}\right]$, biotite and remnants of amphiboles and pyroxenes. Gold is hosted in quartz veins which are confined in brecciated and locally silicified metavolcanic and metasedimentary rocks, intruded 
by post-tectonic mafic and felsic magmas of unknown age (Suh et al., 2006). Gold occurs as small particles disseminated within the quartz matrix and along microfractures within the veins. These veins have as much as $54 \mathrm{ppm}$ gold. The quartz matrix is associated with sphalerite $(\mathrm{ZnS})$, pyrite $(\mathrm{FeS})$, chalcopyrite $\left(\mathrm{CuFeS}_{2}\right)$, arsenopyrite $[(\mathrm{As}, \mathrm{Fe}) \mathrm{S}]$, galena $(\mathrm{PbS})$ and barite $\left(\mathrm{BaSO}_{4}\right)$ and rare pyrrhotite. Freyssinet et al. (1989) identified $\mathrm{Au}-\mathrm{Mo}-\mathrm{W}-\mathrm{Pb}-\mathrm{Bi}$ element association in the host rock and overburden as pathfinder elements for gold in the Lom area.Other ore minerals produced by weathering in the quartz veins are hematite $\left(\mathrm{Fe}_{2} \mathrm{O}_{3}\right)$, covellite and chalcocite (complex hydroxides of $\mathrm{Cu}$ and $\mathrm{Fe}$ ), and psilomelane (Mn hydroxides) (Suh et al., 2006). Although Vairon (1986) attributed a Proterozoic age (2100-2200 Ma, Birrimian) to the Lom series, recent data (Soba et al. 1991) provide evidence of inherited Archaean ages (c. $2500 \mathrm{Ma}$ ) and Neoproterozoic ages (700-1100 Ma) on zircons from detrital material and Neoproterozoic ages (c. $700 \mathrm{Ma}$ ) from metavolcanic rocks in this district. The soil in the area is predominantly acrisols, alisols, plinthosols, acid soil with clay-enriched lower horizon and low saturation of bases.

\section{Method}

\subsection{Sampling Analysis}

Field work was done in the month of February. Sampling was random but purposive (only tailings) over the entire region of Mari artisanal gold mining site. Forty (40) samples were collected comprising of thirty (30) dry tailing samples from the tailing pile and ten (10) wet tailing samples from both active and inactive mining sites. A control sample was collected about $50 \mathrm{~km}$ from Bétaré-Oya town at Ndokayo; a location remote from the mining area in the outskirts of Bétaré-Oya and far removed from the influence of mining activities. Forty one soil samples were shipped to ACME Analytical Laboratory, Canada for chemical analysis. The samples $(0.5 \mathrm{~g})$ were leached in hot $\left(95^{\circ} \mathrm{C}\right)$ Aqua Regia $\left(\mathrm{HNO}_{3} / \mathrm{HCl}\right)$ for 2 hours. The digested sampleswere then cooled and diluted with deionised water and analyzed for their trace metal content by Inductively Coupled Plasma Mass Spectrometry (ICP-MS). Spiked duplicate samples were used to determine precision and bias. In order to allow for data analysis, concentrations below LOQ (limits of quantification) were replaced with half the LOQ for some of the trace elements (USEPA, 2000; Waziri, 2014). While those data points may not be very reliable, this is probably a better alternative to assigning zero concentration or removing the affected samples from the database (Waziri, 2014).

\subsection{Data Treatment Proceduress}

Two pollution indices were used to assess the levels of contamination of the sediments: Enrichment Ratio (ER) and Geoaccumulation index, Igeo:

Enrichment Ratio (ER): Enrichment ratios, adopted from Albright, (2004) were calculated in order to assess the extent of enrichment and /or depletion of trace elements in the soils of the two study areas relative to their crustal concentrations. In this case, the control value was used as the background concentration (1).

$$
\mathrm{ER}=\mathrm{C}_{\mathrm{m}} / \mathrm{B}_{\mathrm{m}}
$$

Where:

$\mathrm{C}_{\mathrm{m}}$ is the concentration of an element measured in a sample and $\mathrm{B}_{\mathrm{m}}$ is the background or baseline concentration, in this case the control value.

Geoaccumulation Index: The index of geoaccumulation (Igeo) actually enables the assessment of contamination by comparing the current and pre-industrial concentrations. Originally used with bottom sediments by Muller (1969), Igeo has widely been applied in the assessment of soil contamination (Likuku, Mmolawa \& Gaboutloeloe, 2013). The geoaccumulation index (Igeo) is expressed as follows (Singh, 2001) (2):

$$
I_{\text {geo }}=\log _{2}\left(\frac{C_{n}}{1.5 \times B_{n}}\right)
$$

Where:

$C n=$ measured metal concentration at sampling point; $B n=$ background concentration value for element; $1.5=$ the background matrix correction factor. The factor 1.5 is introduced to minimize the effect of possible variations in the background values which may be attributed to lithologic variations in soils.

The geoaccumulation index assess contamination based on seven grades $(0-6)$ ranging from unpolluted to very highly polluted. These seven descriptive classes are as follows: $<0=$ practically uncontaminated; $0-1=$ uncontaminated to slightly contaminated; $1-2=$ moderately contaminated; $2-3=$ moderately to highly contaminated; $3-4=$ highly contaminated; $4-5=$ highly to very highly contaminated and $>5=$ very 
highly/strongly contaminated.

\section{Results and Discussion}

\subsection{Trace Element Concentrations}

Table 1 is a summary statistics of chemical analysis of tailings samples (dry and sediment) and comparative concentrations of global crustal averages and trigger values. Gold has the lowest mean concentration followed by $\mathrm{Cd}$ and $\mathrm{W}$, whereas $\mathrm{Ba}$ and $\mathrm{Zr}$ have the highest mean concentrations (579ppm and $651 \mathrm{ppm}$ respectively), similar observations were recorded in the Birim-Gwari (Nigeria) gold mine (Waziri, 2014). Ce, $\mathrm{Zn}, \mathrm{Sr}$ and $\mathrm{Nb}$ have average values of about 50ppm, while the least abundant is $\mathrm{Au}$; for the later, as the element of interest, it is most depleted in the tailings relative to the control soil. Low content can be as a result of low concentration in the original parent rock, and removal during mineral extraction and weathering processes. $\mathrm{W}, \mathrm{Ce}$ and $\mathrm{Nb}$ are generally known to occur in trace quantities in rocks as reflected in the average continental crustal abundance. The elements with the highest concentration, $\mathrm{Ba}$ and $\mathrm{Zr}$ display different patterns that may have a bearing on the processes accounting for their distribution. The abundance of barite, micaschists and granatoids (Suh et al., 2006) of the parent rock which are host to Ba possibly accounts for the high Ba content. In addition, the substitution of $\mathrm{Ba}$ and $\mathrm{Rb}$ for $\mathrm{K}$ in $\mathrm{K}$-feldspar and mica also serves as a source of this element. Mineralisation of feldspar will liberate $\mathrm{Ba}$ which adsorbs onto solid (secondary clay mineral)Fe-(oxy)hydroxides or phosphates particularly during the early stages of weathering (Price, Gray, Wilson, Fray, \& Taylor, 1991).However, considering that K-bearing minerals are relatively more resistant to chemical weathering (Berner and Berner, 1996), release of Ba from them is likely to be limited. In addition, due to its lower solubility (relative to the other alkaline earth metals) $\mathrm{Ba}$ in aqueous systems is likely to be retained in neo-formed clays; thereby increasing its concentration in sediments. Mining activities seem to increase its concentration, such that it is a-par with the values of crustal abundances. $\mathrm{Zr}$ content in the control sample is higher relative to crustal abundance; the former is negatively affected in the mining area (as indicated by the test statistic), considering the mean and standard deviation. $\mathrm{Zr}$ is primarily present in zircon and other heavy minerals in the parent rock.

Table 1. Descriptive statistics for heavy metals and one-sample statistic t-test with test value as Control and comparative trigger concentrations of Continental crust and soils

\begin{tabular}{|c|c|c|c|c|c|c|c|c|c|}
\hline & \multicolumn{6}{|c|}{ This study } & \multicolumn{2}{|c|}{$\begin{array}{c}\text { Continental } \\
\text { crust }\end{array}$} & \multirow[t]{2}{*}{$\begin{array}{c}\text { Trigger \& } \\
\text { intervention }\end{array}$} \\
\hline & Min & Max & Mean & SD & Control & P-value & A & $\mathrm{b}$ & \\
\hline Au & .05 & 4.2 & 1.10 & 0.95 & .05 & $1.12 \mathrm{E}-08$ & & & \\
\hline $\mathrm{Cu}$ & 6 & 58 & 27.60 & 12.83 & 1 & $3.5 \mathrm{E}-16$ & 25 & 25 & $140-720$ \\
\hline Zn & 26 & 111 & 59.00 & 20.59 & 4 & $7.68 \mathrm{E}-20$ & 71 & 65 & $50-100$ \\
\hline As & 5 & 43 & 19.78 & 12.55 & .05 & $1.5 \mathrm{E} 12$ & 1.5 & & 29- 59 \\
\hline $\mathrm{Sr}$ & 20 & 152 & 53.33 & 24.20 & 50 & 0.195 & 350 & 333 & \\
\hline $\mathbf{Y}$ & 16 & 82 & 39.35 & 12.09 & 20 & $9.07 \mathrm{E}-13$ & & & \\
\hline $\mathbf{N b}$ & 23 & 99 & 48.28 & 14.37 & 52 & 0.055 & 25 & 29 & \\
\hline Mo & 1 & 5 & 2.08 & 0.92 & .05 & $4.13 \mathrm{E}-17$ & $1-5$ & & \\
\hline Ag & 2.1 & 18 & 8.21 & 3.90 & .05 & $2.75 \mathrm{E}-16$ & & & \\
\hline Cd & 1 & 2 & 1.20 & 0.41 & 1 & $9.38 \mathrm{E}-21$ & & & $0.8-12$ \\
\hline $\mathbf{S b}$ & 5 & 11 & 6.68 & 2.22 & 1 & $1.31 \mathrm{E}-05$ & & & \\
\hline $\mathbf{B a}$ & 220 & 990 & 578.95 & 183.66 & 112 & 4.19E-19 & 550 & 584 & \\
\hline $\mathbf{L a}$ & 10 & 54 & 20.25 & 10.71 & 8 & 5.18E-09 & 30 & 30 & \\
\hline $\mathrm{Ce}$ & 36 & 164 & 80.85 & 26.07 & 14 & $3.15 \mathrm{E}-19$ & 64 & 60 & \\
\hline $\mathbf{W}$ & 1 & 13 & 3.88 & 3.41 & .05 & 7.74E-09 & & & \\
\hline $\mathbf{P b}$ & 18 & 54 & 31.33 & 8.23 & 5 & $1.4 \mathrm{E}-22$ & 20 & 15 & $85-530$ \\
\hline $\mathbf{Z r}$ & 369 & 1143 & 650.85 & 198.43 & 919 & $8.96 \mathrm{E}-11$ & 190 & 203 & \\
\hline
\end{tabular}

a: Upper continental crust, Taylor and McLennan, (1995); b: Wedepohl, (1995); c: Dutch values Bird et al., (2003) 
The difference in concentration between the tailings sediment and the control is evaluated by the one sample t-test (with the control as the test value). The derived $p$-value $(\alpha=0.05)$ of the test statistics, indicates that the null hypothesis can be rejected (i.e. the difference between the means is less than 0 ) for all elements with the exception of $\mathrm{Sr}$ and $\mathrm{Nb}$.The statistically significant (compared to control) concentration of all elements introduced into the surface soil of the mining area, indicates increases in elemental concentrations in the mining area (i.e. $\mathrm{Au}, \mathrm{Cu}, \mathrm{Zn}, \mathrm{As}, \mathrm{Y}, \mathrm{Mo}, \mathrm{Ag}, \mathrm{Cd}, \mathrm{Sb}, \mathrm{Ba}, \mathrm{La}, \mathrm{Ce}, \mathrm{W}$ and $\mathrm{Pb}$ ). Similar situations have been observed worldwide, such as in the Migori Gold Belt, Kenya, wherein the concentrations of heavy metals in the surface soil of this region, are above acceptable and background levels (Ogola, Mitullah, \& Omula, 2001). Some of these elements can even exceed critical levels.Compared to the crustal abundances, $\mathrm{Sr}$ content in the control sample is lower (about three times), while $\mathrm{Nb}$ is almost twice as high relative to the crustal abundance. Mining has not affected the concentrations of these two elements (following the results of the test statistic). The behavior of $\mathrm{Nb}$ may be due to intense chemical weathering in both the mining and control site. Sr on the other hand may have its concentrations affected by allochtonous depositions in the control area, or leaching from the mining area; thereby maintaining concentrations between the two areas close/unchanged.

A comparison of the content of the tailings and published soil concentration guidelines is undertaken to assess the toxicity of certain elements. As is an element of particular concern in gold mining areas (Carvalho, Neiva, \& Silva, 2009; Inam et al, 2011) where high releases are associated with pollution. Arsenic concentrations in the sediments are significantly higher compared to the control sample as evident in the results of the t-test; inferring a very strong possibility of potential environmental pollution. Gold mine tailings at Obuasi, Ghana for instance, contain very high amounts of As, averagely $8305 \mathrm{mg} / \mathrm{kg}$ (Ahmad \& Carboo, 2000). This has been linked to the considerable level of naturally occurring arsenic at Obuasi, as well as liberations from arsenic-bearing gold ores during gold extraction (Amonoo-Neizer et al., 1995; Ahmad \& Carboo, 2000; Kumi-Boateng, 2007). The As content in the study area is not comparable to that of Obuasi (Ghana).However compared to the soil quality guidelines (Dutch), the values (including standard deviation) have exceeded the target value. The Dutch target values indicate that if concentrations do not exceed this value, the site is considered clean with no eco-toxicological risk. Zn content also falls above the target value.

\subsection{Pollution Indices}

The ER provides an estimate of the changes in concentrations in the examined tailings soils, relative to the background or undisturbed soils (Table 2). Soil from the control area was used as baseline and is referred here as control sample soil. ER of 1 indicates that the soil or sediment is neither enriched nor depleted in a particular element relative to the soil in the control area. Enrichment and depletion are represented by ER values of $>1$ and $<1$ respectively. As (395.5) and $\mathrm{Ag}$ (164) show the highest mean enrichments whereas $\mathrm{Zr}(0.71)$ and $\mathrm{Nb}(0.93)$ are depleted. Considering that As content has been increased almost 400 times as a result of mining is a possible indication of sulphide oxidation processes. Mobility and loss of $\mathrm{Zr}$ during weathering in tropical areas have been reported in literature (Braun,Pagel, Herbillon,\& Rosin, 1993; Colin, Alarcon, \& Vieillard, 1993). Some elements of environmental concerns that have equally been enriched include $\mathrm{Cu}, \mathrm{Zn}, \mathrm{Cd}$ and $\mathrm{Pb}$ indicating that artisanal mining has contaminated the environment with these elements.

Table 2. Summary of indices of Enrichment Ration (ER) for trace elements in tailings sediments $(n=40)$

\begin{tabular}{lllll}
\hline Element & Min & Max & Mean & SD \\
\hline Au & 1.00 & 84.00 & 21.93 & 18.9 \\
$\mathbf{C u}$ & 6.00 & 58.00 & 27.60 & 12.8 \\
$\mathbf{Z n}$ & 6.50 & 27.75 & 14.75 & 5.1 \\
$\mathbf{A s}$ & 100.00 & 860.00 & $\mathbf{3 9 5 . 5 0}$ & 250.9 \\
$\mathbf{S r}$ & 0.40 & 3.04 & 1.07 & 0.5 \\
$\mathbf{Y}$ & 0.80 & 4.10 & 1.97 & 0.6 \\
$\mathbf{N b}$ & 0.44 & 1.90 & 0.93 & 0.3 \\
$\mathbf{M o}$ & 20.00 & 100.00 & 41.65 & 18.3 \\
$\mathbf{A g}$ & 42.00 & 360.00 & $\mathbf{1 6 4 . 1 5}$ & 78.1 \\
$\mathbf{C d}$ & 20.00 & 40.00 & 24.00 & 8.1 \\
\hline
\end{tabular}




\begin{tabular}{lllll}
\hline $\mathbf{S b}$ & 1.00 & 2.20 & 1.34 & 0.4 \\
$\mathbf{B a}$ & 1.96 & 8.84 & 5.17 & 1.6 \\
$\mathbf{L a}$ & 1.25 & 6.75 & 2.53 & 1.3 \\
$\mathbf{C e}$ & 2.57 & 11.71 & 5.78 & 1.9 \\
$\mathbf{W}$ & 20.00 & 260.00 & 77.50 & 68.1 \\
$\mathbf{P b}$ & 3.60 & 10.80 & 6.27 & 1.6 \\
$\mathbf{Z r}$ & 0.40 & 1.25 & 0.71 & 0.2 \\
\hline
\end{tabular}

Table 3 is a summary of the results of the geoaccumulation index. Based on the Igeo classes, the results show that the study area may have problems relating to $\mathrm{Ag}, \mathrm{W}$ and As pollution. Potential contamination problems linked to $\mathrm{As}$ and $\mathrm{Ag}$ have already been cited by ER values. Similarly, $\mathrm{Cu}, \mathrm{Zn}, \mathrm{Mo}$ and $\mathrm{Cd}$ with mean Igeovalue $\geq$ 4 point to possible problems of contamination. $\mathrm{Sr}, \mathrm{Nb}, \mathrm{Sb}$ and $\mathrm{Zr}$ fall within the unpolluted class. Although the nature of the Igeo calculation, which involves the logarithmic function and a background multiplication factor of 1.5 , is somewhat different from ER, the Igeo factors are in general comparable to results reported for ER, as observed in previous studies (i.e. Likuku et. al., 2013).

Table 3. Summary of indices of geoaccumulation, Igeo for trace elements in tailings sediments $(\mathrm{n}=40)$

\begin{tabular}{lcccc}
\hline & Min & Max & Mean & $\mathbf{I}_{\text {geo }}$ Class \\
\hline $\mathbf{A u}$ & -0.58 & 5.81 & 2.68 & 3 \\
$\mathbf{C u}$ & 2.00 & 5.27 & 4.00 & $\mathbf{4}$ \\
$\mathbf{Z n}$ & 2.12 & 4.21 & 3.20 & $\mathbf{4}$ \\
$\mathbf{A s}$ & 6.06 & 9.16 & 7.67 & $\mathbf{6}$ \\
$\mathbf{S r}$ & -1.91 & 1.02 & -0.62 & 0 \\
$\mathbf{Y}$ & -0.91 & 1.45 & 0.33 & 1 \\
$\mathbf{N b}$ & -1.76 & 0.34 & -0.74 & 0 \\
$\mathbf{M o}$ & 3.74 & 6.06 & 4.65 & $\mathbf{5}$ \\
$\mathbf{A g}$ & 4.81 & 7.91 & 6.59 & $\mathbf{6}$ \\
$\mathbf{C d}$ & 3.74 & 4.74 & 3.92 & $\mathbf{4}$ \\
$\mathbf{S b}$ & -0.58 & 0.55 & -0.23 & 0 \\
$\mathbf{B a}$ & 0.39 & 2.56 & 1.69 & 2 \\
$\mathbf{L a}$ & -0.26 & 2.17 & 0.56 & 1 \\
$\mathbf{C e}$ & 0.78 & 2.97 & 1.87 & 2 \\
$\mathbf{W}$ & 3.74 & 7.44 & 5.11 & $\mathbf{6}$ \\
$\mathbf{P b}$ & 1.26 & 2.62 & 1.99 & 2 \\
$\mathbf{Z r}$ & -1.90 & -0.26 & -1.15 & 0 \\
\hline
\end{tabular}

\subsection{Geochemical Association}

Geochemical association is performed with the aim of determining the possible sources of elements, especially potentially toxic ones in the soils and sediments. Multivariate statistical methods in the form of correlation matrix and principal component analysis were used to classify the elements into groups that may signify common origin.

Spearman correlation analysis was performed between all variables (with a level of significance: $p \leq 0.01$ ) and the multi-element correlation for sediment samples was determined and the results are given in Table 4 . The strongest positive association is between $\mathrm{Au}$ and $\mathrm{Ag}$. This association can be explained as the occurrence of Au-Ag alloys (Chapman, Leake, Bond, Stedra, \& Fairgrieve, 2009) of type A in which Ag concentrations in the cores occur as discrete grains having sulfide inclusions and only minor variations in core composition. $\mathrm{Cu}$ and 
$\mathrm{Zn}$ are strongly correlated (0.75), and these two elements are positively correlated with $\mathrm{Sr}$ and $\mathrm{Ba}$ and negative with $\mathrm{Mo}$ and $\mathrm{W} . \mathrm{Cu}$ and $\mathrm{Zn}$ represent mineralization and weathering of sphalerite, chalcopyrite and other sulphide-bearing minerals. According to Teusch, Halicz, \& Chadwick, (1999) $\mathrm{Zn}$ is likely to be associated with organic matter as well as with $\mathrm{Mn}$ and $\mathrm{Al}$ oxides and hydrous oxides, whereas $\mathrm{Cu}$ is probably associated with organic matter. $\mathrm{Ba}$ and $\mathrm{Sr}$ reflect weathering and mineralisation of alkali earth minerals which are hosted in minerals such as feldspars and micas. The association between these elements can partially be explained by the application of $\mathrm{Ba} / \mathrm{Sr}$ ratios as proxy for the weathering of silicate rocks (Dalai, Krishnaswami,\& Sarin, 2002). Negative association between $\mathrm{Cu}-\mathrm{Zn}$ and W-Mo can be explained by the fact that they occur in different petrological associations; the former occur in the quartz matrix hosting the veins associated with the latter. The latter is associated with the gold grains in the veins; this assertion is supported by the identification of $\mathrm{Au}-\mathrm{Mo}-\mathrm{W}-\mathrm{Pb}-\mathrm{Bi}$ element association in the host rock and overburden as pathfinder elements for gold in the Lom area by Freyssinet et al. (1989). A strong correlation is observed between the lithophile elements: $\mathrm{Y}: \mathrm{Nb}(.71), \mathrm{Ce}$ (.79), $\mathrm{La}(.51), \mathrm{Zr}(.31)$. The association with each other is also strong, i.e. $\mathrm{Nb} / \mathrm{Ce}(.73)$ and $\mathrm{La} / \mathrm{Ce}(.63)$. The close association of these elements in the samples may be an indication of the effect of resistant heavy minerals from felsic rocks (mainly granites and gneisses) on the geochemistry of soils and sediments in the area. $\mathrm{Pb}$ displays strong association with the lithophiles, i.e. $0.63,0.63$, and 0.55 for $\mathrm{Y}, \mathrm{Nb}$ and La respectively. Here $\mathrm{Pb}$ could be hosted in the felsic rocks and the resistant heavy minerals. The close association of $\mathrm{Pb}$ with As and $\mathrm{W}$ could relate to $\mathrm{Pb}$ which is present in $\mathrm{S}$-bearing minerals and two of these elements, $\mathrm{W}$ and $\mathrm{Pb}$ are pathfinder for gold in this area (Freyssinet et al. 1989).

Table 4. Spearmen correlation matrix of trace elements, significance $(p \leq 0.01)$

\begin{tabular}{|c|c|c|c|c|c|c|c|c|c|c|c|c|c|c|c|c|c|}
\hline & $\mathrm{Au}$ & $\mathrm{Cu}$ & $\mathrm{Zn}$ & As & $\mathrm{Sr}$ & $\mathrm{Y}$ & $\mathrm{Nb}$ & Mo & $\mathrm{Ag}$ & $\mathrm{Cd}$ & $\mathrm{Sb}$ & $\mathrm{Ba}$ & $\mathrm{La}$ & $\mathrm{Ce}$ & W & $\mathrm{Pb}$ & $\mathrm{Zr}$ \\
\hline $\mathrm{Au}$ & 1.00 & 0.06 & 0.21 & 0.08 & 0.12 & -0.01 & 0.11 & -0.15 & 0.83 & -0.01 & -0.22 & 0.24 & 0.09 & 0.06 & -0.16 & 0.31 & -0.07 \\
\hline $\mathrm{Cu}$ & 0.06 & 1.00 & 0.75 & -0.25 & 0.47 & 0.21 & 0.20 & -0.47 & 0.00 & 0.02 & -0.08 & 0.43 & 0.07 & 0.17 & -0.41 & 0.15 & -0.18 \\
\hline $\mathrm{Zn}$ & 0.21 & 0.75 & 1.00 & -0.21 & 0.58 & 0.29 & 0.24 & -0.38 & 0.07 & -0.08 & -0.19 & 0.54 & 0.04 & 0.20 & -0.31 & 0.30 & 0.08 \\
\hline As & 0.08 & -0.25 & -0.21 & 1.00 & -0.30 & 0.07 & 0.16 & 0.26 & 0.00 & -0.23 & 0.31 & -0.08 & 0.24 & 0.12 & 0.65 & 0.40 & -0.09 \\
\hline $\mathrm{Sr}$ & 0.12 & 0.47 & 0.58 & -0.30 & 1.00 & -0.10 & 0.09 & -0.21 & 0.01 & -0.24 & -0.35 & 0.53 & -0.23 & 0.18 & -0.23 & 0.04 & 0.20 \\
\hline $\mathrm{Y}$ & -0.01 & 0.21 & 0.29 & 0.07 & -0.10 & 1.00 & 0.71 & -0.17 & 0.11 & -0.25 & 0.10 & -0.05 & 0.51 & 0.72 & -0.11 & 0.42 & 0.31 \\
\hline $\mathrm{Nb}$ & 0.11 & 0.20 & 0.24 & 0.16 & 0.09 & 0.71 & 1.00 & -0.04 & 0.19 & -0.23 & 0.02 & -0.10 & 0.48 & 0.79 & -0.06 & 0.63 & 0.31 \\
\hline Mo & -0.15 & -0.47 & -0.38 & 0.26 & -0.21 & -0.17 & -0.04 & 1.00 & -0.10 & 0.06 & -0.04 & -0.13 & 0.13 & -0.03 & 0.28 & 0.07 & -0.04 \\
\hline $\mathrm{Ag}$ & 0.83 & 0.00 & 0.07 & 0.00 & 0.01 & 0.11 & 0.19 & -0.10 & 1.00 & 0.01 & -0.32 & 0.17 & 0.09 & 0.14 & -0.19 & 0.32 & 0.00 \\
\hline $\mathrm{Cd}$ & -0.01 & 0.02 & -0.08 & -0.23 & -0.24 & -0.25 & -0.23 & 0.06 & 0.01 & 1.00 & -0.13 & -0.14 & 0.05 & -0.27 & -0.40 & 0.01 & -0.36 \\
\hline $\mathrm{Sb}$ & -0.22 & -0.08 & -0.19 & 0.31 & -0.35 & 0.10 & 0.02 & -0.04 & -0.32 & -0.13 & 1.00 & -0.15 & 0.01 & 0.06 & 0.31 & 0.03 & -0.02 \\
\hline $\mathrm{Ba}$ & 0.24 & 0.43 & 0.54 & -0.08 & 0.53 & -0.05 & -0.10 & -0.13 & 0.17 & -0.14 & -0.15 & 1.00 & 0.04 & 0.11 & -0.16 & 0.22 & 0.02 \\
\hline $\mathrm{La}$ & 0.09 & 0.07 & 0.04 & 0.24 & -0.23 & 0.51 & 0.48 & 0.13 & 0.09 & 0.05 & 0.01 & 0.04 & 1.00 & 0.60 & -0.04 & 0.55 & 0.05 \\
\hline $\mathrm{Ce}$ & 0.06 & 0.17 & 0.20 & 0.12 & 0.18 & 0.72 & 0.79 & -0.03 & 0.14 & -0.27 & 0.06 & 0.11 & 0.60 & 1.00 & -0.17 & 0.64 & 0.40 \\
\hline W & -0.16 & -0.41 & -0.31 & 0.65 & -0.23 & -0.11 & -0.06 & 0.28 & -0.19 & -0.40 & 0.31 & -0.16 & -0.04 & -0.17 & 1.00 & 0.05 & -0.08 \\
\hline $\mathrm{Pb}$ & 0.31 & 0.15 & 0.30 & 0.40 & 0.04 & 0.42 & 0.63 & 0.07 & 0.32 & 0.01 & 0.03 & 0.22 & 0.55 & 0.64 & 0.05 & 1.00 & 0.15 \\
\hline $\mathrm{Zr}$ & -0.07 & -0.18 & 0.08 & -0.09 & 0.20 & 0.31 & 0.31 & -0.04 & 0.00 & -0.36 & -0.02 & 0.02 & 0.05 & 0.40 & -0.08 & 0.15 & 1.00 \\
\hline
\end{tabular}

Principal component analysis was conducted in order to further assess the relationship patterns. While PCA does not show what controls the distribution of elements, it is useful for drawing inferences from elemental associations. Varimax orthogonal rotation was applied to the PCA in order to minimize the effects of non-normal data (Gong et al., 2010), especially the effects of high concentrations. Five components (Table 5), explaining about $71.16 \%$ of the variance were extracted. Component 1 is associated with loadings of lithophiles (Y, Nb, La, $\mathrm{Ce})$ along with $\mathrm{Pb}$. This relationship has already been revealed in the correlation matrix and again is interpreted as an indication of effect of resistant heavy minerals from felsic rocks (mainly granites and gneisses) on the geochemistry of soils and sediments in the area. Component 2 is positively correlated with $\mathrm{Cu}, \mathrm{Zn}, \mathrm{Sr}$ and $\mathrm{Ba}$. This relationship too has been indicated in the correlation matrix and is associated with mineralisation and clay 
formation from weathering. The third component is negatively associated with $\mathrm{Au}$ and $\mathrm{Ag}$; a relationship that has already been observed from the correlation matrix.The last two components have As and $\mathrm{W}$ which correlates positively and; $\mathrm{Sr}$ and $\mathrm{Zr}$ correlating negatively with $\mathrm{Cd}$. The presence of $\mathrm{Sr}$, along with $\mathrm{Zr}$ may support the fact that the distribution of this element may also be associated with anthropogenic and allochtonous deposition, as suggested by the insignificant variation between the mining and control areas.

Table 5. Total variance explained for trace element contents in tailings sediments

\begin{tabular}{rrrrrrrrrr}
\hline Component & \multicolumn{3}{c}{ Initial Eigenvalues } & \multicolumn{3}{c}{ Extraction sums of Squared loadings } & \multicolumn{3}{c}{ Rotation sums of squared loadings } \\
& Total & Var. \% & Cum \% & Total & Var. \% & Cum. \% & Total & Var. \% & Cum. \% \\
\hline $\mathbf{1}$ & 3.68 & 21.63 & 21.62 & 3.67 & 21.62 & 21.62 & 3.5 & 20.57 & 20.57 \\
$\mathbf{2}$ & 3.19 & 18.74 & 40.36 & 3.19 & 18.74 & 40.36 & 2.75 & 16.19 & 36.76 \\
$\mathbf{3}$ & 2.06 & 12.12 & 52.48 & 2.06 & 12.12 & 52.48 & 2.11 & 12.39 & 49.15 \\
$\mathbf{4}$ & 1.63 & 9.56 & 62.04 & 1.63 & 9.56 & 62.04 & 2.09 & 12.28 & 61.43 \\
$\mathbf{5}$ & 1.55 & 9.12 & 71.17 & 1.55 & 9.12 & 71.17 & 1.65 & 9.73 & 71.16 \\
$\mathbf{6}$ & 1.22 & 7.15 & 78.32 & & & & & & \\
\hline
\end{tabular}

Table 6. Rotated component matrix for trace elements contents of tailings sediments

\begin{tabular}{llllll}
\hline Component & $\mathbf{1}$ & $\mathbf{2}$ & $\mathbf{3}$ & $\mathbf{4}$ & $\mathbf{5}$ \\
\hline $\mathbf{Y}$ & 0.83 & & & & \\
$\mathbf{N b}$ & 0.75 & & & & \\
$\mathbf{L a}$ & 0.79 & & & & \\
$\mathbf{C e}$ & 0.90 & & & & \\
$\mathbf{P b}$ & 0.69 & & & & \\
$\mathbf{C u}$ & & 0.86 & & & \\
$\mathbf{Z n}$ & & 0.87 & & & \\
$\mathbf{S r}$ & & 0.55 & & & 0.59 \\
$\mathbf{B a}$ & & 0.67 & & & \\
$\mathbf{A u}$ & & & -0.90 & & \\
$\mathbf{A g}$ & & & -0.94 & & \\
$\mathbf{A s}$ & & & & 0.86 & \\
$\mathbf{W}$ & & & & 0.81 & \\
$\mathbf{C d}$ & & & & & -.76 \\
$\mathbf{Z r}$ & & & & & 0.63 \\
\hline
\end{tabular}

In conclusion, the results identify $\mathrm{Ba}$ and $\mathrm{Zr}$ to have the highest mean concentrations (579 and $651 \mathrm{ppm}$ respectively). All the elements (i.e. $\mathrm{Au}, \mathrm{Cu}, \mathrm{Zn}, \mathrm{As}, \mathrm{Y}, \mathrm{Mo}, \mathrm{Ag}, \mathrm{Cd}, \mathrm{Sb}, \mathrm{Ba}, \mathrm{La}, \mathrm{Ce}, \mathrm{W}$ and $\mathrm{Pb}$ ) with the exception of $\mathrm{Sr}$ and $\mathrm{Nb}$ have increased in the mining area and similar situations have been reported worldwide (e.g. Ogola et al., 200; Waziri et al., 2014). $\mathrm{Nb}$ trends can be attributed to its generally reported immobile nature, whereas for $\mathrm{Sr}$, it is suggested that extensive leaching in the mining area and/or allochtonous deposition in the control area may be influence its distribution. Pollution indices identified potential pollutants to include $\mathrm{Cu}, \mathrm{Zn}, \mathrm{As}$, W, Mo and Ag. Compared to the Dutch soil quality guidelines, these elements are above the target values and below the intervention level. Among these As is considered the most threatening, considering its potency. The distribution of As in this area appears to be controlled by mining activities. $\mathrm{Cu}, \mathrm{Zn}, \mathrm{Sr}$ and $\mathrm{Ba}$ distribution is associated with mineralisation of sulphide-bearing minerals and clay formation from weathering of mica schist.

\section{References}

Ahmad, K., \& Carboo, D. (2000). Speciation of As (III) and As (V) in some Ghanaian gold tailings by a simple 
distillation method. Water, Air Soil Pollution, 122, 317-326. https://doi.org/10.1023/A:1005286832435

Albright, E. I. (2004). Background concentrations of trace elements in soils and rocks of the Georgia Piedmont. (Unpublished Master's thesis), The University of Georgia.

Amonoo-Neizer, E. H., Nyamah, D., \& Bakiamoh, S. B. (1995). Mercury and arsenic pollution in soil and biological samples around the mining town of Obuasi, Ghana. Water, Air Soil Pollution, 91, 363-373. https://doi.org/10.1007/BF00666270

Babut, M. et al. (2003). Improving the environmental management of small-scale gold mining in Ghana: a case study of Dumasi. Journal of Cleaner Production, 11, 215-221. https://doi.org/10.1016/S0959-6526(02)00042-2

Bird, G., Brewer, P. A., Macklin, M. G., Balteanu, D., Driga, B., Serban, M., \& Zaharia, S. (2003). The solid state partitioning of contaminant metals and As in river channel sediments of the mining affected Tisa drainage basin, northwestern Romania and eastern Hungary. Applied Geochemistry, 18, 1583-1595. https://doi.org/10.1016/S0883-2927(03)00078-7

Braun, J. J., Pagel, M., Herbillon, A., \& Rosin, C. (1993). Mobilizationand redistribution of REEs and thorium in a syenitic lateritic profile:A mass balance study. Geochim. Cosmochim. Acta, 57, 4419-4434. https://doi.org/10.1016/0016-7037(93)90492-f

Carvalho, P. C. S., Neiva, A. M. R., \& Silva, M. M. V. G. (2009). Geochemistry of stream sediments and waters close to abandoned W-Au-Sb mines at Sarzedas, Castelo Branco, central Portugal. Geochem. Explor. Environ Anal, 9, 341-352. https://doi.org/10.1144/1467-7873/09-208

Chapman, R. J., Leake, R. C., Bond, D. P. G., Stedra, V., \& Fairgrieve, B. (2009). Chemical and mineralogical signatures of gold formed in oxidizing chloride hydrothermal systems and their significance within populations of placer gold grains collected during reconnaissance. Econ. Geol., 104, 563-585. https://doi.org/10.2113/gsecongeo.104.4.563

Colin, F., Alarcon, C., \& Vieillard, P. (1993) Zircon: An immobileindex in soils? Chem. Geol., 107, 273-276. https://doi.org/10.1016/0009-2541(93)90189-p

Dalai, T. K., Krishnaswami, S., \& Sarin, M. M. (2002). Barium in the Yamuna River System in the Himalaya:Sources, fluxes, and its behavior during weathering andtransport. Geochemistry. Geophysics Geosystems, 3(12). https://doi.org/10.1029/2002GC000381

Freyssinet, P. H., Lecomte, P., \& Edimo, A. (1989). Dispersion of gold and base metals in the Mborguene lateritic profile, East Cameroon. Journal of Geochemical Exploration, 32, 99-116. https://doi.org/10.1016/0375-6742(89)90050-2

Gong, M. et al. (2010). Assessing heavy metal contamination and sources by GIS based approach and multivariate analysis of urban-rural top soils in Wuhan, central China. Environ Geochem Health, 32, 59-72. https://doi.org/10.1007/s10653-009-9265-2

Hilson, G. (2002). The environmental impact of small-scale mining in Ghana: identifying problems and possible solutions. The Geogr. Jour., 168(1), 57-72. https://doi.org/10.1111/1475-4959.00038

Inam, E., Khantotong, S., Kim, K., Tumendemberel, B., Erdenetsetseg, S., \& Puntsag, T. (2011). Geochemical distribution of trace element concentrations in the vicinity of Boroo gold mine, Selenge Province, Mongolia. Environ Geochem Health, 33, 57-69. https://doi.org/10.1007/s10653-010-9347-1

Kumi-Boateng, B. (2007). Assessing the spatial distribution of arsenic concentration from goldmine for environmental management at Obuasi, Ghana. (Unpublished Master's thesis). International Institute for Geo-Infomatics. Science and Earth Observation, Enschede, The Netherlands.

Likuku, A. S., Mmolawa, K. B., \& Gaboutloeloe, G. K. (2013) Assessment of Heavy Metal Enrichment and Degree of Contamination Around the Copper-Nickel Mine in the Selebi Phikwe Region, Eastern Botswana. Environment and Ecology Research, 1(2), 32-40.

Malaviya, S., Munsi, M., Oinam, G., \& Joshi, P. (2010). Landscape approach for quanitifying land use land cover change (1972-2006) and habitat diversity in a mining area in Central India (Bokaro, Jharkhand). Environmental monitoring and Assessment, 170, 215-229. https://doi.org/10.1007/s10661-009-1227-8

Muller, G. (1971). Schwermetalle in den sedimenten des Rheins-Verendrrungen Seit Umschau, 79 p. 778.

Ogola, J. S., Mitullah, W. V., \& Omula, M. A. (2001). Impact of gold mining on the environment and Human 
Health: A case study in the Migori Gold Belt, Kenya. Environmental. Geochemistry and Health, 24, 141158. https://doi.org/10.1023/A:1014207832471

Price, R. C., Gray, C. M., Wilson, R. E., Fray, F. A., \& Taylor, S. R. (1991). The effect of weathering on rare earth element, Y and Ba abundances in Tertiary basalts from southeastern Australia. Chemical Geology, 93, 245-265. https://doi.org/10.1016/0009-2541(91)90117-A

Simmons, J. A., Curie, W. S., Eschleman, K. N., Kuers, K., Monteleone, S., \& Negley, T. L. (2008). Forest to reclaim land mine use change leads to altered ecosystem structure and function. Ecologocal Applications, 18, 104-118. https://doi.org/10.1890/07-1117.1

Singh, M. (2001). Heavy metal pollution in freshly deposited sediments of the Yamnne River (the Ganges River Tributary): a case study from Dehli and Agra Urban centers, India. Environmental Geology, 40, 664. https://doi.org/10.1007/s002549900091

Soba, D. et al. (1991) Données géochronologiques nouvelles (Rb-Sr, U-Pb et Sm-Nd) sur la zone mobile panafricaine de l'Est Cameroun: Age protérozoique supérieur dela série de Lom. Comptes rendus de l'Académie des sciences de Paris, 315, 1453-1458.

Suh, C. E., Lehmann, B., \& Mafany, G. T. (2006). Geology and geochemical aspects of lode gold mineralization at Dimako-Mboscorro, SE Cameroon. Geochemistry: Exploration, Environment, Analysis, 6, 295-309. https://doi.org/10.1144/1467-7873/06-110

Tarras-Wahlberg, N. H., Flachier, A., Fredrikson, G. Lane, S. N., Lundberg, B., \& Sangfors, O. (2000). Environmental impact of small-scale and artisanal gold mining in southern Ecuador: implications forthe setting of environmental standards and the management of small scale mining. Ambio, 29, 484-491. https://doi.org/10.1579/0044-7447-29.8.484

Taylor, S. R., \& McLennan, S. M. (1995). The geochemical evolution of continental crust. Rev Geophysics, 33(2), 241-265. https://doi.org/10.1029/95RG00262

Teutsch, N., Erel, Y., Halicz, L., \& Chadwick, O. A. (1999). The influence of rainfall on metal concentration and behaviour in the soil. Geochimica et Cosmochimica Acta, 63(21), 3499-3511. https://doi.org/10.1016/S0016-7037(99)00152-0

USEPA. (1994). Design and evaluation of tailings dams. Technical Report - EPA530-R-94-038. USEPA, Office of Solid Waste, SpecialWaste Branch, Washington, DC.

USEPA. (2000). Assigning values to non-detected/ non-quantified pesticide residue in human food exposure assessments. Office of Pesticide Programs. Retrieved November 15, 2012, from http://www.epa.gov/oppfead1/trac/science/trac3b012.pdf

Waziri, N. M. (2014). Environmental Geochemistry of Soils and Stream Sediments from the Birnin-Gwari Artisanal Gold Mining Area, North-western Nigeria. Universal Journal of Geoscience, 2(1), 18-27.

Wedepohl, K. H. (1995). The composition of the continental crust. Geochim Cosmochim Acta, 59(7), 1217-1232. https://doi.org/10.1016/0016-7037(95)00038-2

\section{Copyrights}

Copyright for this article is retained by the author(s), with first publication rights granted to the journal.

This is an open-access article distributed under the terms and conditions of the Creative Commons Attribution license (http://creativecommons.org/licenses/by/4.0/). 